\title{
Noise Measurements in Timber Industries
}

\section{Mjerenje buke u drvnoj industriji}

\author{
Professional paper • Stručni rad \\ Received-prispjelo: 3. 6. 2013. \\ Accepted-prihvaćeno: 23. 6. 2014. \\ UDK: $630 * 83 ; 674.02 ; 502 / 504$ \\ doi:10.5552/drind.2014.1334
}

\begin{abstract}
The intensification of industrial production and the concurrent increase in machine operation speeds has led to the rise in the intensity of noise generated in most workplaces. The purpose of the present paper is to investigate occupational noise exposure in timber processing units. For this reason, a number of measurements were carried out in various parts of three sawmills. Maximum allowable exposure limits (permissible levels) were set at $85 \mathrm{~dB}(A)$ for the production area and warehouses, and $55 \mathrm{~dB}(A)$ for offices. According to the results of the study, the production area in a sawmill gives rise to higher levels of noise compared to warehouses and offices, which significantly exceed maximum permissible levels. More specifically, the highest noise levels recorded were found to be produced by cutting machinery. In such cases it is imperative that employees be protected either with the use of personal hearing protectors or with the implementation of a regular break scheme. In addition, substantial reduction in noise levels can be achieved with the use of other protective measures such as control of noise at its source or in its path.
\end{abstract}

Keywords: noise pollution, hearing loss, occupational disease, sawmills

SAŽETAK • Intenziviranje industrijske proizvodnje i istodoban porast brzine rada strojeva dovelo je do porasta intenziteta buke kojom je opterećena većina radnih mjesta u drvnoj industriji. Cilj ovog rada bio je istražiti izloženost buci na radnim mjestima u pogonima za industrijsku preradu drva. Stoga su provedena mjerenja buke na različitim radnim mjestima u tri pilane. Granična vrijednost buke (dopuštena razina) kojoj mogu biti izloženi radnici iznosi 85 $d B(A)$ za područje proizvodnje i skladišta te $55 d B(A)$ za uredske prostore. Prema rezultatima studije, u proizvodnim pogonima pilane izmjerene su više razine buke nego u skladištima i uredskim prostorima, a izmjerene razine buke znatno premašuju najveću dopuštenu razinu. Najviše razine buke izmjerene su na radnim mjestima uz strojeve za mehaničku obradu drva. U takvim uvjetima zaposlenici moraju biti zaštićeni od prekomjerne izloženosti buci upotrebom osobnih zaštitnih sredstava ili skraćivanjem vremena provedenog na radnome mjestu uvođenjem redovitih stanki tijekom radnog vremena. Osim toga, znatno se smanjenje razine buke može postići i primjenom drugih zaštitnih mjera kao što su kontrola i smanjenje buke na izvoru ili na putu njezina širenja.

Ključne riječi: buka, gubitak sluha, profesionalne bolesti, pilana

\section{INTRODUCTION}

\section{UVOD}

Nowadays, noise is one of the main sources of annoyance (Skenberg and Öhrström, 2002). Consequently, it is considered as a form of "invisible pollution", called noise-pollution (Dafis, 1998). At the be- ginning of the $20^{\text {th }}$ century, one of the fathers of modern hygienology, Robert Koch, wrote that "the day will come when man will have to fight noise as inexorably as cholera and the plague" (in Grivas, 2007). Noise is defined as every kind of unwanted and disturbing sound that threatens our physical, psychological and social well-being (Peippo et al., 2000; Ouis, 2001).

\footnotetext{
${ }^{1}$ Author is assistant professor at Department of Forestry and Management of the Environment and Natural Resources, Demokrition University of Thrace, Orestiada, Greece.

${ }^{1}$ Autor je docent Odjela za šumarstvo i menadžment okoliša i prirodnih resursa, Sveučilište u Thraseu, Kavala, Grčka.
} 
The methods used to assess noise levels that are emitted from various types of machinery are described in ISO 3740 (2001), which also includes all the basic ISO standards related to noise. Besides, ISO TC 43 is a point of reference for issues of noise (Laios and Giannakourou-Sioutari, 2003).

Noise pollution can be the cause of a multitude of problems that modern man is affected by, the most significant being: damage to hearing resulting in hearing loss, cardiac disorders, various health problems like high blood pressure, migraines, ulcer, asthma, pregnancy disorders, learning disabilities in children, loss of efficiency and concentration at work, sleep disturbance, etc. (Arana and Garcia, 1997; Stansfeld, 1992; Ouis, 2001; Skenberk and Öhrström, 2002; Job et al., 1996).

At the workplace, exposure to high-level noise can seriously impair communication between employees and, depending on the level, frequency and duration of exposure, it can adversely affect workers' physical and psychological health (Shaikh, 1999; Kryter, 1970; Donald-Siu, 2001). One of the most serious consequences of high-level noise is the irreparable damage to human hearing (Irle et al., 1998; Niu-Canlon, 2002). Exposure to high noise levels at work has been associated with a significant increase in work-related accidents; in addition, the so-called "occupational noiseinduced hearing loss" is considered the most frequent work-related disease.

According to the $2^{\text {nd }}$ European Survey on Working Conditions (ESWC), the workplaces that are most exposed to noise are (HSE, 1998):

- Metal Industries

- Timber Industries

- Base metal industries

- Paper industries

- Construction

- Fiber Industries.

Out of the above listed workplaces, Metal and Timber Industries are the most hazardous noise-generating environments, on the grounds that they use a series of processes and a great number of machines for the shaping and handling of materials (HSE, 1998). These processes produce extremely high and protracted volumes of noise at the workplace. For this reason, the European law sets certain limits to the exposure of workers to noise, according to which noise should, under no circumstances, exceed an average of $87 \mathrm{~dB}(\mathrm{~A})$ on one hand and on the other for levels exceeding 80 $\mathrm{dB}(\mathrm{A})$, proper hearing protection (earplugs or earmuffs) is compulsory (MSFC-STD-267).

Hearing loss is listed among the occupational diseases included in Article 40 of Disease Regulations issued by the Greek Social Security Organization - IKA (published in Government Gazette No. 132/12.2.1979). The same document specifies that a minimum of 5 years of employment is required to officially recognize a hearing loss and establish it as an occupational disease. Table 1 shows the percentage of workers suffering from hearing loss in relation to years of exposure and noise levels over an eight-hour working day.
Table 1 Probability of hearing loss among workers in relation to years of exposure and noise levels for an eight-hour day (Grandjean, 1997)

Tablica 1. Vjerojatnost gubitka sluha radnika u ovisnosti o razini buke i godinama izloženosti buci tijekom osamsatnoga radnog dana

\begin{tabular}{|c|c|c|c|}
\hline $\begin{array}{c}\text { Noise level } \\
\text { Razina buke } \\
\mathrm{dB}(\mathrm{A})\end{array}$ & $\begin{array}{c}\text { 5 years } \\
5 \text { godina }\end{array}$ & $\begin{array}{c}\mathbf{1 0} \text { years } \\
\text { 10 godina }\end{array}$ & $\begin{array}{c}\text { 20 years } \\
\text { 20 godina }\end{array}$ \\
\hline 80 & $0 \%$ & $0 \%$ & $0 \%$ \\
\hline 90 & $4 \%$ & $10 \%$ & $16 \%$ \\
\hline 100 & $12 \%$ & $29 \%$ & $42 \%$ \\
\hline 110 & $26 \%$ & $55 \%$ & $78 \%$ \\
\hline
\end{tabular}

Under the Control of Noise at Work Presidential Decree 85/91, the health of the workers receiving high noise doses should be protected. More specifically, the Decree makes it imperative that employers take certain technical and organizational precautions, should levels reach $85 \mathrm{~dB}(\mathrm{~A})$; in addition, maximum exposure limit for an 8-hour day is set at $90 \mathrm{~dB}(\mathrm{~A})$ (Marhavilas, 2010).

Physicists use a logarithmic scale for measuring sound pressure (Sound Pressure Level - SPL), namely the decibel $(\mathrm{dB})$ scale. The decibel is a number that represents the logarithm of a ratio between a given sound pressure and a reference value:

$$
S P L=20 \cdot \log \left(P / P_{O}\right)
$$

where $P$ is the square root of the mean square value of the sound pressure of a stimulus and $P_{0}$ the reference pressure (usually a barely perceptible sound, called the threshold of human hearing) (Laios and Giannakourou-Sioutari, 2003).

The decibel as a logarithmic unit has a very significant role in determining sound levels at workplaces: every increase of sound intensity equal to $3 \mathrm{~dB}(\mathrm{~A})$ doubles the energy that the human ear receives, meaning that the double of $85 \mathrm{~dB}(\mathrm{~A})$ is not 170 but $88 \mathrm{~dB}(\mathrm{~A})$ (Grivas, 2007).

Most sound measuring instruments take into account the variations in the sensitivity of the human ear as far as the frequency of the sounds is concerned. For this reason, various frequency weighting methods have been developed to approximate the way the human ear responds to noise levels. The most widely used method of measurement is called "A-weighting" and the equivalent unit of pressure is $\mathrm{dB}(\mathrm{A})$ (Laios and Giannakourou-Sioutari, 2003).

Sustained exposure to $80 \mathrm{~dB}(\mathrm{~A})$ throughout the working day is considered to be the safety limit under which a worker does not run the risk of developing occupational noise-induced hearing loss (HSE, 1998).

Noises equal to or exceeding $85 \mathrm{~dB}(\mathrm{~A})$ with continuous distribution in the range of acoustic frequencies (from 15 to $20.000 \mathrm{~Hz}$ ) are considered dangerous, regardless of exposure duration, necessitating the use of hearing protectors. Maximum permissible noise exposure is set at $115 \mathrm{~dB}(\mathrm{~A})$ for a period that does not exceed 2 min per 24 hours (Laios and GiannakourouSioutari, 2003). Presidential Decree 85/1991, in accordance with the European Union Directive, requires the reduction of noise at its source so that a worker's daily 
exposure does not exceed $90 \mathrm{~dB}(\mathrm{~A})$. For this reason, when exposures exceed $85 \mathrm{~dB}(\mathrm{~A})$, employers are obliged to supply workers with Personal Protective Equipment (PPE). Table 2 shows the recommended use of PPE in relation to noise levels.

Table 2 Use of Personal Protective Equipment (PPE) in relation to noise levels (Presidential Decree 85/1991)

Tablica 2. Uporaba osobnih zaštitnih sredstava ovisno o razini buke (Presidential Decree 85/1991)

\begin{tabular}{|c|c|c|}
\hline $\begin{array}{c}\text { Noise levels, } \\
\mathbf{d B}(\mathbf{A}) \\
\text { Razina buke, } \\
d B(A)\end{array}$ & $\begin{array}{c}\text { Description } \\
\text { Opis }\end{array}$ & $\begin{array}{c}\text { Use of PPE } \\
\text { Uporaba osobnih } \\
\text { zaštitnih } \\
\text { sredstava }\end{array}$ \\
\hline$<74$ & $\begin{array}{c}\text { Good conditions } \\
\text { dobri uvjeti }\end{array}$ & $\begin{array}{c}\text { Use not required } \\
\text { ne zahtijeva se }\end{array}$ \\
\hline $75-80$ & $\begin{array}{c}\text { Tolerable conditions } \\
\text { podnošljivi uvjeti }\end{array}$ & $\begin{array}{c}\text { Use not required } \\
\text { ne zahtijeva se }\end{array}$ \\
\hline $81-84$ & $\begin{array}{c}\text { Noisy conditions } \\
\text { bučni uvjeti }\end{array}$ & $\begin{array}{c}\text { Use not required } \\
\text { ne zahtijeva se }\end{array}$ \\
\hline $85-87$ & $\begin{array}{c}\text { Very noisy conditions } \\
\text { vrlo bučni uvjeti }\end{array}$ & $\begin{array}{c}\text { Use required } \\
\text { zahtijeva se }\end{array}$ \\
\hline$>88$ & $\begin{array}{c}\text { Intolerable conditions } \\
\text { nepodnošljivi uvjeti }\end{array}$ & $\begin{array}{c}\text { Use required } \\
\text { zahtijeva se }\end{array}$ \\
\hline
\end{tabular}

In the USA, under the Occupational Safety \& Health Administration, workers with daily exposures to an average noise level of $85 \mathrm{~dB}(\mathrm{~A})$ or higher must be protected with the implementation of proper preventive measures (reduction of noise emissions, removal of noise sources, etc) or with proper personal protective equipment. The maximum permissible exposure levels are shown in Table 3 (Laios and GiannakourouSioutari, 2003).

Table 3 Maximum Permissible Exposure Levels (OSHA 1910.95/1998)

Tablica 3. Maksimalno dopuštena razina izloženosti buci (OSHA 1910.95/1998)

\begin{tabular}{|c|c|}
\hline $\begin{array}{c}\text { Daily exposure (hours) } \\
\text { Dnevna izloženost (sati) }\end{array}$ & $\begin{array}{c}\text { Noise level } \\
\text { Razina buke } \\
\mathrm{dB}(\mathrm{A})\end{array}$ \\
\hline 8 & 90 \\
\hline 6 & 92 \\
\hline 4 & 95 \\
\hline 3 & 97 \\
\hline 2 & 100 \\
\hline 1.5 & 102 \\
\hline 1 & 105 \\
\hline 0.5 & 110 \\
\hline 0.25 & 115 \\
\hline
\end{tabular}

Workers who live in environments with highlevel noise have reduced opportunities for communication, the consequences of which are far-reaching since it is difficult for signals or warnings of danger to be heard.

Systematic research on occupational noise-induced hearing loss has never been carried out in Greece. There are certain publications, of course, but they do not contain epidemiological data and consequently the extent of the problem is not fully known.
The Greek law is in accordance with the European law; however we do not know if it is thoroughly applied. For this reason, it is considered crucial to carry out the present research in order to highlight all the aspects of the problem so that protective measures may be taken for employees.

The aim of the present study is to investigate the noise levels to which timber industry workers are exposed on a daily basis.

\section{MATERIALS AND METHODS 2. MATERIJAL I METODE}

Research was conducted in timber industries. Three typical sawmills, located in Drama, Northern Greece, were chosen, in which numerous measurements were carried out. The aim of the study was to assess noise generated by various timber processing machines, both at individual workstations and in its totality, as well as the extent of its impact on the staff, consisting of machine operators and the rest of the employees.

At the beginning, the machines were classified into groups depending on the kind of processing they performed. As a result, the following groups were formed:

- Cutting machinery (multi-rip saw, band saw, log cutter, edger, circular saw, planer - moulder, wood profile cutter, etc);

- Planing machinery;

- Other machines (absorption machines, boilers, etc).

Measurements were carried out while machines processed timber coming from spruce (Picea excelsa), beech (Fagus silvatica), black pine (Pinus nigra) and poplar sp. (Populus sp.) Subsequently, it was deemed equally necessary to conduct measurements in areas located outside the productive process, such as warehouses and offices, so as to acquire a complete picture of the problem and its effects.

All noise monitoring was conducted with a digital, portable sound level meter designed in compliance with DIN 45633, JIS 1502, IEC 651 specifications.

During the sampling process, two kinds of measurements were performed: a) measurement of the overall noise pollution generated in the place, and b) measurement of the noise pollution recorded in each operator workstation. In total, 7 locations were chosen in the general area and their selection was made on the basis of the layout of the place. Finally, it was decided that the individual workstations of the operators should be of the same number as the machines.

In each assessment site in the general area a total of 40 measurements were carried out ( 1 every $15 \mathrm{sec}$ onds), whereas in each machine area 80 measurements were performed (40 with the machine in operation and another 40 with the machine in idling mode.) The processed timber was classified into two groups: the first contained logs of small dimensions, whose diameter in the middle was below $30 \mathrm{~cm}$, whereas the second contained thick logs, with a diameter in the middle of over $30 \mathrm{~cm}$. 


\section{RESULTS AND DISCUSSION}

\section{REZULTATI I RASPRAVA}

The results of noise monitoring are shown in Table 4 to 8 . Table 4 illustrates noise levels produced in three sawmills, with Sawmill A consisting of two production places, Room 1 and Room 2. It can be observed here that noise levels are on average high (in excess of $90 \mathrm{~dB}(\mathrm{~A}))$ in all sawmills and on certain occasions they reach almost $99 \mathrm{~dB}(\mathrm{~A})$.

Table 4 Noise levels produced in the sawmills Tablica 4. Rezultati mjerenja razine buke u tri pilane

\begin{tabular}{|l|c|c|c|c|}
\hline $\begin{array}{l}\text { Noise intensity, } \\
\text { dB(A) }\end{array}$ & \multicolumn{2}{|c|}{$\begin{array}{c}\text { Sawmill A } \\
\text { Pilana A }\end{array}$} & $\begin{array}{c}\text { Saw- } \\
\text { mill B }\end{array}$ & $\begin{array}{c}\text { Sawmill } \\
\text { C } \\
d B(A)\end{array}$ \\
\cline { 2 - 3 } $\begin{array}{l}\text { Room 1 } \\
\text { Mean }\end{array}$ & $\begin{array}{c}\text { Room } \\
\text { pogon 1. }\end{array}$ & $\begin{array}{c}\text { Pilana } \\
\text { pogon 2. }\end{array}$ & $\begin{array}{c}\text { Pilana } \\
\text { C }\end{array}$ \\
\hline MAX & 90.1 & 88.46 & 96.14 & 96.59 \\
\hline MIN & 91.6 & 89.67 & 97.56 & 97.8 \\
\hline $\begin{array}{l}\text { Number of } \\
\text { measurements } \\
\text { Broj mjerenja }\end{array}$ & 249.5 & 87.56 & 94.56 & 95 \\
\hline
\end{tabular}

Table 5 provides a comprehensive picture of the volume of noise produced by different machine groups. Cutting machinery produces the highest level of noise reaching approximately $97.46 \mathrm{~dB}(\mathrm{~A})$, whereas planing machinery generates the lowest noise levels (an average of $88.76 \mathrm{~dB}(\mathrm{~A})$ ). The rest of the machines produce levels falling between these two extremes. It is noteworthy that all groups of machinery cause noise that is higher than the $85 \mathrm{~dB}(\mathrm{~A})$ permissible level.

Table 5 Intensity of noise generated by various types of machinery in timber processing units

Tablica 5. Intenzitet buke što ju emitiraju različiti strojevi u pogonima za preradu drva

\begin{tabular}{|c|c|c|c|c|}
\hline \multirow[b]{2}{*}{$\begin{array}{l}\text { Type of machinery } \\
\text { Vrsta stroja }\end{array}$} & \multirow{2}{*}{$\begin{array}{c}\text { Number } \\
\text { of } \\
\text { machines } \\
\text { Broj } \\
\text { strojeva }\end{array}$} & \multicolumn{3}{|c|}{$\begin{array}{c}\text { Noise intensity, } \mathbf{d B}(\mathbf{A}) \\
\text { Intenzitet buke, } d B(A)\end{array}$} \\
\hline & & \begin{tabular}{|c|} 
Mean \\
Srednja \\
vrijednost
\end{tabular} & $\begin{array}{c}\text { Max } \\
\text { Maks. }\end{array}$ & $\begin{array}{l}\text { Min } \\
\text { Min. }\end{array}$ \\
\hline $\begin{array}{l}\text { Cutting machinery } \\
\text { Strojevi za rezanje }\end{array}$ & 20 & 95.35 & 97.46 & 94.47 \\
\hline $\begin{array}{l}\text { Planing machinery } \\
\text { Strojevi za blanjanje }\end{array}$ & 2 & 88.76 & 91 & 87 \\
\hline $\begin{array}{l}\text { Other machines } \\
\text { Ostali strojevi }\end{array}$ & 2 & 92.54 & 93.5 & 90.5 \\
\hline
\end{tabular}

Total number of measurements: 1680

Table 6 presents noise levels corresponding to each machine. The noisiest machines (producing almost $100 \mathrm{~dB}(\mathrm{~A}))$ were found to be the wood profile

Table 6 Noise levels generated by various machines in timber processing units

Tablica 6. Razina buke koju emitiraju različiti strojevi u pogonima za preradu drva

\begin{tabular}{|c|c|c|c|c|c|c|c|c|}
\hline \multirow[t]{2}{*}{$\begin{array}{l}\text { Machine } \\
\text { Naziv stroja }\end{array}$} & \multirow{2}{*}{$\begin{array}{c}\text { Number of } \\
\text { machines } \\
\text { Broj } \\
\text { strojeva }\end{array}$} & \multicolumn{2}{|c|}{$\begin{array}{c}\text { Mean } \\
\text { Srednja vrijednost }\end{array}$} & \multicolumn{2}{|c|}{$\begin{array}{l}\text { Max } \\
\text { Maks. }\end{array}$} & \multicolumn{2}{|c|}{$\begin{array}{l}\text { Min } \\
\text { Min. }\end{array}$} & \multirow{2}{*}{$\begin{array}{c}\text { Type of } \\
\text { machinery } \\
\text { Vrsta stroja }\end{array}$} \\
\hline & & $\begin{array}{c}\text { in operation } \\
\text { pod optere- } \\
\text { ćenjem }\end{array}$ & $\begin{array}{l}\text { in idling } \\
\text { mode } \\
\text { u praznom } \\
\text { hodu }\end{array}$ & $\begin{array}{l}\text { in opera- } \\
\text { tion / pod } \\
\text { optereće- } \\
\text { njem }\end{array}$ & $\begin{array}{c}\text { in idling } \\
\text { mode } \\
\text { u praznom } \\
\text { hodu }\end{array}$ & $\begin{array}{l}\text { in opera- } \\
\text { tion } \\
\text { pod opte- } \\
\text { rećenjem }\end{array}$ & $\begin{array}{c}\text { in idling } \\
\text { mode } \\
\text { u praznom } \\
\text { hodu }\end{array}$ & \\
\hline $\begin{array}{l}\text { Multi-rip saw } \\
\text { višelisna pila }\end{array}$ & \multirow[t]{2}{*}{1} & 95 & 94.28 & 97 & 95 & 95 & 93 & \multirow[t]{2}{*}{1} \\
\hline Total / ukupno & & \multicolumn{2}{|c|}{94.64} & \multicolumn{2}{|c|}{96} & \multicolumn{2}{|c|}{93.5} & \\
\hline $\begin{array}{l}\text { Band saw } \\
\text { tračna pila }\end{array}$ & \multirow[t]{2}{*}{8} & 92.1 & 91.55 & 94.25 & 92,83 & 92,83 & 92,16 & \multirow[t]{2}{*}{1} \\
\hline Total / ukupno & & \multicolumn{2}{|c|}{91.83} & \multicolumn{2}{|c|}{93.54} & \multicolumn{2}{|c|}{91.37} & \\
\hline $\begin{array}{l}\text { Log cutter } \\
\text { iverači za trupce }\end{array}$ & \multirow[t]{2}{*}{2} & 99.33 & 96.88 & 100 & 100 & 100 & 96,5 & \multirow[t]{2}{*}{1} \\
\hline Total / ukupno & & \multicolumn{2}{|c|}{98.105} & \multicolumn{2}{|c|}{100} & \multicolumn{2}{|c|}{95.5} & \\
\hline $\begin{array}{l}\text { Edger / stroj za } \\
\text { okrajčivanje }\end{array}$ & \multirow[t]{2}{*}{3} & 96.08 & 94.33 & 97.67 & 95,67 & 95,67 & 95 & \multirow[t]{2}{*}{1} \\
\hline Total / ukupno & & \multicolumn{2}{|c|}{95.21} & \multicolumn{2}{|c|}{96.67} & \multicolumn{2}{|c|}{94.17} & \\
\hline $\begin{array}{l}\text { Circular saw } \\
\text { kružna pila }\end{array}$ & \multirow[t]{2}{*}{4} & 95.42 & 93.95 & 96.83 & 98,17 & 95,17 & 94,5 & \multirow[t]{2}{*}{1} \\
\hline Total / ukupno & & \multicolumn{2}{|c|}{94.68} & \multicolumn{2}{|c|}{96} & \multicolumn{2}{|c|}{92.75} & \\
\hline $\begin{array}{l}\text { Absorption } \\
\text { odsisni uređaj }\end{array}$ & 1 & \multicolumn{2}{|c|}{99.75} & \multicolumn{2}{|c|}{100} & \multicolumn{2}{|c|}{97} & 3 \\
\hline $\begin{array}{l}\text { Planer - moulder } \\
\text { Blanjalica-glodalica }\end{array}$ & 1 & \multicolumn{2}{|c|}{95.92} & \multicolumn{2}{|c|}{100} & 9 & 5 & 1 \\
\hline $\begin{array}{l}\text { Wood profile cutter } \\
\text { profilni centar }\end{array}$ & 1 & 99. & & & 00 & 9 & 9 & 1 \\
\hline Boiler / kotao & 1 & 85. & & & 37 & 8 & 34 & 3 \\
\hline $\begin{array}{l}\text { Sharpening machines } \\
\text { strojevi za oštrenje }\end{array}$ & 2 & 88. & & & 1 & & 37 & 2 \\
\hline
\end{tabular}

Total number of measurements: 1680 
cutter, log cutter and absorption machine, followed by multi-rip saw, planer and edger (around $95 \mathrm{~dB}(\mathrm{~A})$ ). Less annoyance is produced by the boiler, whose noise level is at an average of $85.32 \mathrm{~dB}(\mathrm{~A})$. In other words, it can be seen that only the boiler is within the $85 \mathrm{~dB}(\mathrm{~A})$ permissible noise limit.

The results also reveal that the noise produced is higher in large width logs (with a mean diameter of over $30 \mathrm{~cm}$ ). This is true for most cutting machines (such as the band saw).

It is noteworthy that in the general area, and not only in the proximity of a machine operator (Table 7), noise levels are clearly in excess of $85 \mathrm{~dB}(\mathrm{~A})$, reaching an average of approximately $90 \mathrm{~dB}(\mathrm{~A})$. At an operator's workstation, the difference between levels produced by a machine in operation and in idling mode is on average $1.5 \mathrm{~dB}(\mathrm{~A})$. This difference is considered significant bearing in mind that a $3 \mathrm{~dB}$ difference in actuality means that the ear receives double energy.

The majority of the employees participating in the present study were between 35 and 45 years of age. When asked if noise was a nuisance during work, most of them answered that it was quite annoying but they have become used to it and, generally speaking, they had no hearing complaints. They also said that they made no use of earmuffs or plugs. Their tolerance toward an everyday problem such as noise pollution can be accounted for only by their short period of employment since most of them said that they had been working in sawmills for less than 5 years.

Table 7 Noise generated in various assessment sites Tablica 7. Razina buke na različitim radnim mjestima

\begin{tabular}{|l|c|c|c|}
\hline \multirow{2}{*}{$\begin{array}{c}\text { Measurement site } \\
\text { Mjesto mjerenja }\end{array}$} & \multicolumn{3}{|c|}{$\begin{array}{c}\text { Noise intensity, dB(A) } \\
\text { Intenzitet buke, } d B(A)\end{array}$} \\
\cline { 2 - 4 } & $\begin{array}{c}\text { Mean } \\
\text { Srednja } \\
\text { vrijednost }\end{array}$ & $\begin{array}{c}\text { Max } \\
\text { Maks. }\end{array}$ & $\begin{array}{c}\text { Min } \\
\text { Min. }\end{array}$ \\
\hline $\begin{array}{l}\text { Production area } \\
\text { Proizvodni pogon }\end{array}$ & 89.2 & 91.3 & 88.6 \\
\hline $\begin{array}{l}\text { Operator site (machine in } \\
\text { operation) / Radno mjesto } \\
\text { operatera stroja (stroj je pod } \\
\text { opterećenjem) }\end{array}$ & 95.6 & 97.1 & 95.7 \\
\hline $\begin{array}{l}\text { Operator site (machine in idling } \\
\text { mode) / Radno mjesto operatera } \\
\text { stroja (stroj je u praznom hodu) }\end{array}$ & 94.2 & 96.3 & 92.2 \\
\hline
\end{tabular}

Total number of measurements: 1720

As illustrated in Table 8, in the rest of the work areas noise levels are tolerable since they often drop below $55 \mathrm{~dB}(\mathrm{~A})$ (e.g. in offices).

As far as offices are concerned, as well as places where employee concentration is essential, international standards require that maximum noise exposure be set at $55 \mathrm{~dB}(\mathrm{~A})$. Under Norwegian law, in jobs where critical communication is involved, noise levels must not exceed $55 \mathrm{~dB}(\mathrm{~A})$ (Koukoulaki, 2008).

Figure 1 gives a comparative picture of noise generated by the machines monitored in the study, in relation to the $85 \mathrm{~dB}(\mathrm{~A})$ permissible level for an 8 -hour work day.
Table 8 Noise levels generated in various parts of the timber factory

Tablica 8. Razina buke u različitim prostorima tvrtke za preradu drva

\begin{tabular}{|l|c|c|c|}
\hline \multirow{2}{*}{$\begin{array}{c}\text { Measurement site } \\
\text { Mjesto mjerenja }\end{array}$} & \multicolumn{3}{|c|}{$\begin{array}{c}\text { Noise intensity, } \mathbf{d B}(\mathbf{A}) \\
\text { Intenzitet buke, } d B(A)\end{array}$} \\
\cline { 2 - 4 } & $\begin{array}{c}\text { Mean } \\
\text { Srednja vrijednost }\end{array}$ & $\begin{array}{c}\text { Max } \\
\text { Maks. }\end{array}$ & $\begin{array}{c}\text { Min } \\
\text { Min. }\end{array}$ \\
\hline Warehouse / Skladište & 67.7 & 69 & 67 \\
\hline Office / Uredski prostori & 21.15 & 25 & 18 \\
\hline
\end{tabular}

Total number of measurements: 80

\begin{tabular}{|lc|}
\hline $\begin{array}{l}\text { Multi-rip saw / višelisna } \\
\text { kružna pila }\end{array}$ & $\square$ Planer - moulder \\
& blanjalica - glodalica \\
$\square$ Band saw / tračna pila & $\square$ Wood profile cutter \\
$\square$ Log cutter / prikrajač trupaca & profiler \\
$\square$ Edger / okrajčivač & Boiler / grijač \\
$\square$ Circular saw / kružna pila & $\square$ Sanders / brusilice \\
$\square$ Absorption / ekshaucija & $\square$ Permissible Noise Level Exposure \\
\hline
\end{tabular}

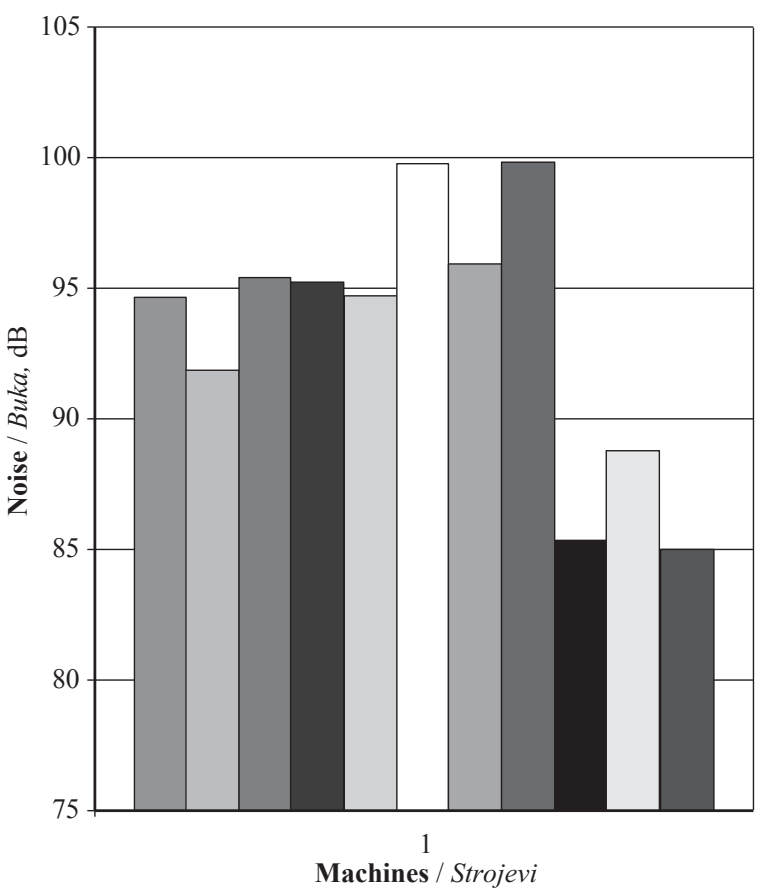

Figure 1 Noise generated by different machines in various parts of the timber factory in relation to the $85 \mathrm{~dB}(\mathrm{~A})$ permissible level

Slika 1. Izmjerena razina buke različitih strojeva i u različitim prostorijama pogona za preradu drva u usporedbi $\mathrm{s}$ graničnom razinom buke od $85 \mathrm{~dB}(\mathrm{~A})$

\section{CONCLUSIONS 4. ZAKLJUČAK}

According to the findings of the present study, noise levels generated in sawmills are generally above the rationally accepted exposure standards in all parts of the sawmill with the exception of the offices.

The highest volume of noise is emitted from the cutting machinery, especially the multi-rip saw, log cutter and wood profile cutter. The boiler is the only machine that does not exceed the $85 \mathrm{~dB}(\mathrm{~A})$ permissible level. 
The extent of annoyance is also in close relation with the dimensions of the material that is cut and the type of timber.

The production area generally gives rise to highlevel noise, above the acceptable threshold, whereas in the offices and warehouses noise levels are comparatively low.

Workers and especially operators of most machines are exposed to such noise levels that it is quite possible that their health will be adversely affected on a temporary or permanent basis. The precautions that are necessary to be taken so as to reduce the amount and impact of noise are, first of all, the proper marking by the organization of noise generating zones with suitable notices. In addition, it is imperative that a special program of hearing protection be implemented. In the attempt to improve the noise environment at the workplace, crucial preventive actions to be taken include control of noise at its source; this can be done with measures such as the design of the whole productive process in a specific area aimed at minimizing the amount of noise-pollution.

clude:

Other measures that organizations can take in-

- Improve the design of machines (e.g. by supplying them with shock absorbers and anti-vibration mounting, installing protective Plexiglas enclosures, etc). Where possible, use special covers, silencers and generally materials with strong anti-vibration capacity.

- When technically feasible, reduce emission of noise by placing a barrier between the noise source and the employee (e.g. a sound-proof cabin).

- Increase the distance between the noise source and the worker.

- Use special sound absorbing materials on the walls, ceilings and floor of noisy areas. Provide workers with personal protective devices such as suitable earmuffs and plugs.

- Use tools and equipment with anti-noise design. Choose electrical tools instead of compressed air tools. Fit rubber pads that are specially designed to absorb vibration. Maintain equipment properly since poorly maintained machinery can increase sound emissions. Reduce the speed of cutting, sawing and spinning (Facts)

- Limit the amount of time an employee spends at a noise source. This can be implemented when workers take it in turns to spend time at very noisy areas.

- Provide quiet areas where workers can spend time in order to gain relief from hazardous noisy environments.

\section{REFERENCES}

\section{LIERATURA}

1. Arana, M.; Garcia, A., 1997: A social survey on the effects of environmental noise on the residents of Pamplona, Spain. Applied Acoustics, 53(4): 245-253. http://dx.doi.org/10.1016/S0003-682X(97)00067-4

2. Gradjean, E., 1997: Fitting the task to the man: a textbook of occupational ergonomics. $5^{\text {th }}$ ed.
3. Government Gazette No 132/12.2.1979): List of occupational diseases defined in Article 40, Disease Regulations, Greek Social Security Organization (I.K.A).

4. Grivas, S., 2007: Journal of the Greek Institute for Health $\&$ Safety at Work. ELINYAE eds, Athens.

5. Donald, I.; Siu, O., 2001: Moderating the stress impact of environmental conditions: The effect of organizational commitment in Hong-Kong and China. Journal of Environmental Psychology, 21(4): 353-368.

http://dx.doi.org/10.1006/jevp.2001.0229

6. Facts, European Agency for Safety and Health at Work, http:// hefp.aua.gr/sites/efp.aua.gr/files/yli_arch_13.doc 16-01-2014

7. Health and Safety Executive (HSE), 1998: Noise at work - What action should you take?

8. Irle, H.; Hesse, J. M.; Strasser, H., 1998: Physiological cost of energy-equivalent noise exposures with a rating level of $85 \mathrm{~dB}(\mathrm{~A})$. International Journal of Industrial Ergonomics 21: 451-463. http://dx.doi.org/10.1016/S0169-8141(96)00082-0

9. ISO 3740, 2001: Acoustics. Determination of sound power levels of noise sources. Guidelines for the use of basic standards (BS EN ISO 3740).

10. ISO TC 43: Acoustics. Standardization in the field of acoustics, including methods of of measuring acoustical phenomena, their generation, transmission and reception, and all aspects of their effects on man and his environment.

11. Job, R. F. S. et al., 1996: The influence of subjective reactions to noise on health effects of the noise. Environmental International, 22(1): 93-104. http://dx.doi.org/10.1016/0160-4120(95)00107-7

12. Koukoulaki, Th., 2008: Assessment and Prevention of Occupational Risk in Telecommunications. Journal of the Greek Institute for Health \& Safety at Work. ELINYAE eds. Athens.

13. Kryter, K., 1970: The effects of noise on man. New York: Academic Press.

14. Kryter, K., 1994: The handbook of hearing and the effects of noise. New York: Academic Press.

15. Laios, L.; Giannakourou-Sioutari, M., 2003: Modern Ergonomy. Papasotiriou eds., Athens.

16. Marhavilas, P., 2010: Impact of Natural Factors on the Workplace: Electromagnetic Radiation, Noise, Lighting, Heating Conditions. Lecture Notes. Department of Electrical and Computer Engineering. Democritus University of Thrace.

17. MSFC-STD-267, A Human Engineering Design Criteria, NASA-MSFC, 09-23-66.

18. Niu, X.; Canlon, B., 2002: Protecting against noise trauma by sound conditioning. Journal of Sound and Vibration, 250 (1): 115-118. http://dx.doi.org/10.1006/jsvi.2001.3899

19. Dafis, S. A., 1998: Urban Forestry (Urban Forestry), $2^{\text {nd }}$ ed. A.U.Th., Thessaloniki.

20. Occupational Safety and Health Administration., 1998: OSHA Regulation 1910, Subart G, 1910.95 Occupational noise exposure (Code of Federal Regulations, FR291910.95, pp. 194-206), Washington, DC: U.S. Government Printing Office.

21. Ouis, D., 2001: Annoyance from Road Traffic Noise: A Review. Journal of Environmental Psychology, 21: 101120. http://dx.doi.org/10.1006/jevp.2000.0187

22. Presidential Decree 149/2006: Minimum health and safety specifications for the exposure of employees to hazards coming from natural sources (noise) in accordance with Directive 2003/10/EC. Government Gazette of Greece No 159/28.7.2006, Athens. 
23. Presidential Decree 85/1991: Protection of employees from dangers of noise exposure at work, in accordance with Directive 86/188/EEC. Government Gazette of Greece No 38/A/18.3.1991, Athens.

24. Peippo, M.; Hakkala, M.; Heikkinen, M., 2000: Road Traffic Noise: Turku urban area. PSSD Taskreport. Baltic Region Healthy Cities Office, Regional Council of Southwest Finland, p. 26.

25. Shaikh, G. H., 1999: Occupational noise exposure limits for developing countries. Applied Acoustics 57: 89-92. http://dx.doi.org/10.1016/S0003-682X(98)00038-3

26. Skenberg, A.; Öhrström, E., 2002: Adverse health effects in relation to urban residential soundscapes. Journal of Sound and Vibration, 250 (1): 151-155. http://dx.doi.org/10.1006/jsvi.2001.3894
27. Stansfeld, S. A., 1992: Noise, noise sensitivity and psychiatric disorder: Epidemiological and psychophysiological studies. Psychological Medicine, 22: 41-44.

\section{Corresponding address:}

Assist. Prof. VASILIKI DIMOU, Ph.D.

Demokrition University of Thrace

Department of Forestry and Management of the Environment and Natural Resources

Institute of Timber Harvest

Pantazidou Str. 193

8200 Orestiada, GREECE

e-mail:vdimou@fmenr.duth.gr 